\title{
BUILDING AND STANDARDIZATION TEST SPEED AND ACCURACY OF THE SCORING FROM THE FOOTBALL SIDE OF THE HALLS OF THE PLAYERS OF THE TRAINING CENTER FOR THE INTERMEDIATE STAGE IN THE PROVINCE OF BAGHDAD
}

\author{
Noor Sabah Lawwas, Prof.Dr. Mawahib Hamid Noman \\ University of Baghdad / College of Physical Education and Sports Science for Girls
}

DOI: $10.37648 / \mathrm{ijrssh} . v 10 \mathrm{i01} .021$

Received:04 $4^{\text {th }}$ October 2019; Accepted:23 $3^{\text {rd }}$ November, 2019; Published: 04 ${ }^{\text {th }}$ December, 2019

\section{ABSTRACT:}

The goal of the research is based on building and standardizing a test to measure the speed and accuracy of scoring from the side of the football players for the intermediate stage in Baghdad province, and to find the levels and standard scores on which teachers and coaches depend, and the researcher used the descriptive approach, and the research community represents the players of the training centers for intermediate stage in Baghdad province The number of (164) players, and the statistical transactions were extracted using the statistical bag ready (SPSS.Ver15) for the proposed test, and the researcher concluded an appropriate and validity of the test designed to measure the speed and accuracy of scoring from the side of the football players for the intermediate stage Baghdad province, and then recommended the researcher to use the designer test to measure the speed and accuracy of scoring from the side of the football players of the lounges.

Keywords: Building - scoring from the side - football lounges.

\section{INTRODUCTION}

Our modern world is witnessing a great and rapid interest in the use of teaching aids and technology in various fields and the most prominent sports field, as ideas and methods emerged in human thought were not common or circulating in the sports sectors to reach the state of creativity and innovation in the process of learning skills and sports movements through creating an environment Suitable for learning and education
Composite tests are the scientific way to know the efficiency of football players of the halls in the skills of composite and scoring, and through the tests can design modern exercises simulate the performance of the team. Objective tests can identify high player levels and low player levels.

:research importance

The importance of research lies through finding a scientific means through the design of tests of the skills and the construction of building and codification in the 
game of soccer halls to facilitate the process of learning for some of the skills of composite intermediate stage players in the province of Baghdad, and through testing can save time and effort and facilitate the training process for those involved in the game of football Foot lounges to learn the abilities and levels of players and develop appropriate solutions through training curricula.

:Previous studies

Previous studies in the design (composite tests), NajiKazim study (2010), Saher Mohammed Humaid AlDulaimi (2016), previous studies in the type of game (football for the halls), the study sent Abdulmutallab Abdul Hamza (2011), study Ayed Ali Athab Al-Saadi (2014), Previous Studies on Students, DiaaMounirFadelShawkat Study (2006), Haytham Jawad Kazem Study (2018).

:Research problem

Standardized tests are a requirement of the game of football halls, through which the player can reach the highest levels during the competition in the game of football halls, and the game needs to test complexes in the privacy of the game and through which the strengths of the team can be diagnosed.

As a researcher looking forward to the training centers and has experience in this area and after conducting personal interviews with a number of professors, specialists and trainers for the intermediate stage, it was noted the lack of use of composite tests in the game of football halls, which coincides with the development in education and to bring the players to the best level of education in terms of development And learn composite skill to achieve better achievement and high level in the future, which is consistent and simulate the skills of the vehicle in this game.

Therefore, the researcher considered studying the problem in building and standardizing a test to measure the speed and accuracy of the scoring from the side of the football players of the halls of the middle stage in Baghdad province.

:Purpose of the study

Building and standardizing the speed and accuracy of the scoring test from the side of the football players to the intermediate stage in Baghdad province.

:search limits

A sample of the players of the training centers of the middle fun in the game of football halls in the province of Baghdad (2018, 2019).

\section{MATERIALS AND METHODS:}

The researcher used the descriptive method to suit the nature of the research.

Research community and sample:

The research community was determined by the players of the training centers for the intermediate stage in the province of Baghdad for the year $(2018,2019)$ where the total sample of the total research (147) players divided into three groups as follows the first group eleven players for the exploratory experiment and the second group reached (64) players to adjust The extraction of scientific transactions The third group reached (72) players were used for rationing.

$\square$ Means of gathering information, tools and equipment used for research:

.Arab and foreign sources -

.Football for the lounges -

.Interviews with experts in the game of football for the halls -

.- Form of registration of test results

.Persons -

Field research procedures -

$\square$ Test design

Designed by the researcher to test the speed and accuracy of scoring from the side of the football players for the intermediate stage in Baghdad province through a questionnaire to survey the views of specialists and experts test and measurement and science training in the game of football to find out the validity of the (compound test) and design as finalized, and after surveying the opinions of specialists and their agreement However, the "composite test" can be applied to the ground after the rationing process.

- Test Search: Test the rolling speed of the side and pull the ball and the accuracy of scoring distance $(10 \mathrm{~m})$

Test name: rolling speed of the side and pull the ball and scoring accuracy at a distance $(10 \mathrm{~m})$

The goal of the test: rolling speed of the side and pull the ball and accuracy of scoring

Tools used: Football and soccer halls and wall divides the target into (5) sections and whistle.

How to perform: The player stands at the side line with the ball and when you hear the whistle the player rolls the ball from the side line to the person who is $(3 \mathrm{~m})$ and then pull the ball inside the foot when a person and then 
(IJRSSH) 2020, Vol. No. 10, Issue No. I, Jan-Mar

scoring on the goal divided, which is away from the goal (10 m)

Score: Calculated by Ft (1) (degree / time)

$\square$ (2) Two scores when scoring in allocatedarea (2)
e-ISSN: 2249-4642, p-ISSN: 2454-4671

degrees when scoring in the allocated area No. (4) degrees when scoring in the allocated area No. (6)

$\square$ One degree when touching the crossbar or post.

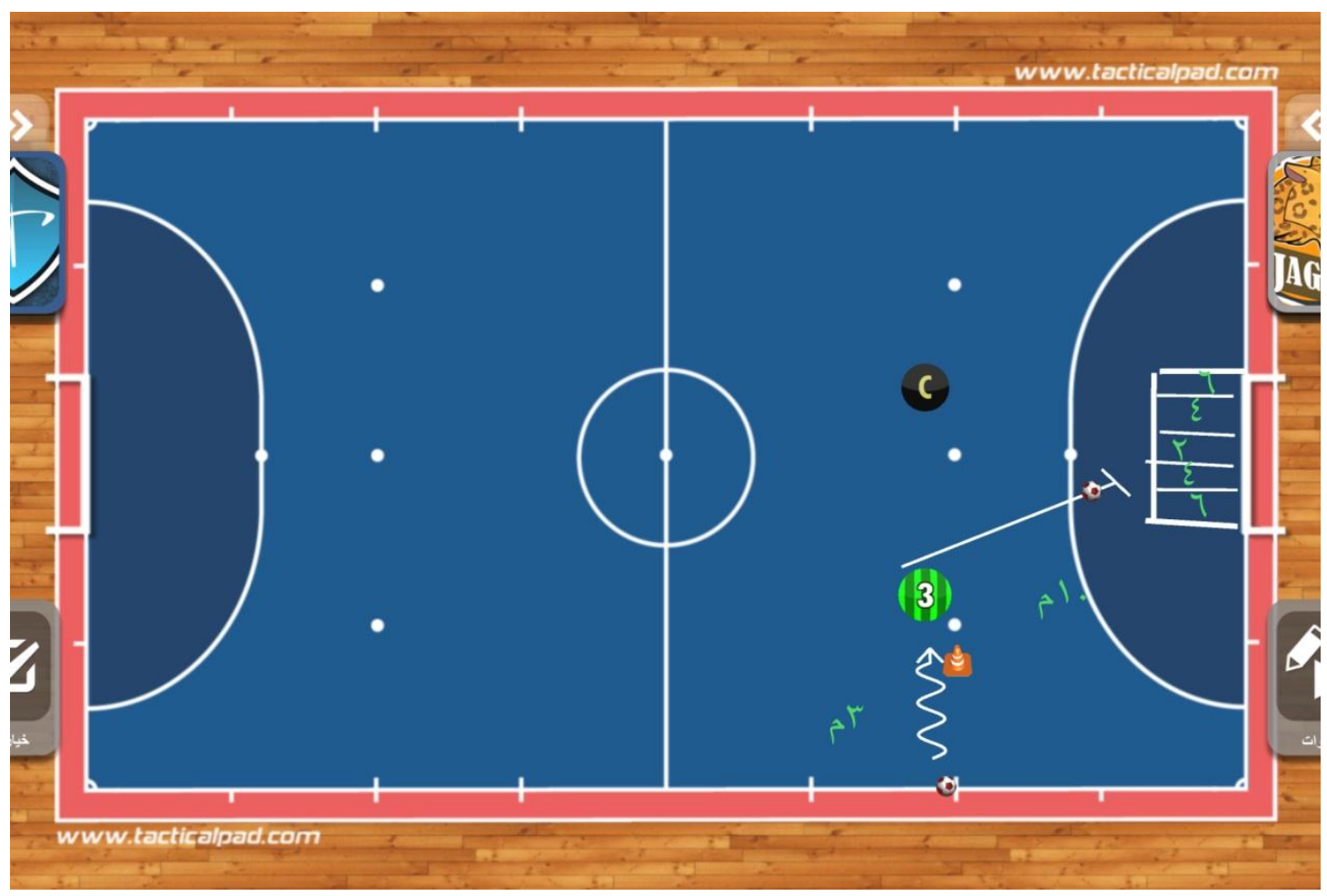

Scientific basis for testing:

$\square$ Sincerity test:

Hisham Al-Zyoud and Nader Alian (1998) believe that the test is sincere. The proposed test forms (compound) were distributed to (9) specialists and experts ( $\square$ )

$\square$ Discriminatory honesty (discriminatory ability to test)

A test can be considered honest if it can distinguish between the highest scores of the test and the minimum scores of the test it measures. It also emphasizes (Salahuddin Mahmoud Allam 2011) "provide a test based on the identification of weak students and strong students in achievement" (). To find out the discriminatory power of the two tests of the construction sample of (64) players after ranking hierarchically from the largest degree to the smallest degree, and the proportion $(26.56 \%)$ of the highest scores, which was represented by (17) players to match (26.56\%) of the lower scores (17) players were excluded $(46.87 \%)$ for the average scores, which was (30) players. The calculation is smaller than the approved significance level (0.05), and this proves the discriminatory validity of the test (compound) as shown in Table (1) 
(IJRSSH) 2020, Vol. No. 10, Issue No. I, Jan-Mar

e-ISSN: 2249-4642, p-ISSN: 2454-4671

Shows the discriminatory power of the complex test

\begin{tabular}{|c|c|c|c|c|c|c|c|c|}
\hline \multirow[t]{2}{*}{ Significance } & \multirow{2}{*}{$\begin{array}{l}\text { Error } \\
\text { level }\end{array}$} & \multirow{2}{*}{$\begin{array}{l}\text { Calculate } \\
\text { d value }\end{array}$} & \multicolumn{2}{|c|}{ Total minimum levels } & \multicolumn{2}{|c|}{ Total upper levels } & \multirow{2}{*}{$\begin{array}{l}\text { measuring } \\
\text { unit }\end{array}$} & \multirow{2}{*}{$\begin{array}{l}\text { Statistical } \\
\text { parameters } \\
\text { the exams }\end{array}$} \\
\hline & & & $\begin{array}{l}\text { standard } \\
\text { deviatio } \\
\mathrm{n}\end{array}$ & $\begin{array}{l}\text { Arithmetic } \\
\text { mean }\end{array}$ & $\begin{array}{l}\text { standard } \\
\text { deviation }\end{array}$ & $\begin{array}{l}\text { Arithmetic } \\
\text { mean }\end{array}$ & & \\
\hline moral & 0.000 & 9.047 & 0.166 & 0.477 & 0.233 & 1.108 & $\begin{array}{l}\text { Degree/ } \\
\text { second }\end{array}$ & $\begin{array}{l}\text { Rolling speed } \\
\text { from the side } \\
\text { and pulling the } \\
\text { ball and } \\
\text { scoring on a } \\
\text { goal divided at } \\
10 \mathrm{~m}\end{array}$ \\
\hline
\end{tabular}

Below the significance level (0.05) and the degree of freedom 32

:Test stability

Stability should be available in a successful test. Stability is an important scientific basis. The stability of the test was found by re-testing (compound) (second application) after seven days on Friday, Saturday and Sunday $(3,2,1) / 3 / 2018$ on the construction sample of sixty-four players and the researcher used the correlation coefficient (Pearson) To identify the correlation between the first test and the second test, the results of the test showed a correlation coefficient and (significant significance) when the error level of the test (compound) is less than the error level (0.05) as shown in Table (2)

Shows the stability of the tests:

\begin{tabular}{|c|c|c|c|c|c|c|c|c|}
\hline \multirow[t]{2}{*}{ Significance } & \multirow{2}{*}{$\begin{array}{l}\text { Error } \\
\text { level }\end{array}$} & \multirow{2}{*}{$\begin{array}{l}\text { The } \\
\text { value } \\
\text { of } t\end{array}$} & \multicolumn{2}{|c|}{ exam REPETITON } & \multicolumn{2}{|c|}{ The first test } & \multirow{2}{*}{$\begin{array}{l}\text { measuring } \\
\text { unit }\end{array}$} & \multirow{2}{*}{$\begin{array}{l}\begin{array}{l}\text { Statistical } \\
\text { parameters }\end{array} \\
\text { the exams }\end{array}$} \\
\hline & & & $\begin{array}{l}\text { standard } \\
\text { deviation }\end{array}$ & $\begin{array}{l}\text { Arithmetic } \\
\text { mean }\end{array}$ & $\begin{array}{l}\text { standard } \\
\text { deviation }\end{array}$ & Arithmetic mean & & \\
\hline moral & 0.000 & $\begin{array}{l}0.80 \\
0\end{array}$ & 0.406 & 0.840 & 0.399 & 0.798 & $\begin{array}{l}\text { Degree/ } \\
\text { second }\end{array}$ & $\begin{array}{l}\text { Rolling speed } \\
\text { from the side and } \\
\text { pulling the ball } \\
\text { and scoring on a } \\
\text { goal divided at } \\
10 \mathrm{~m}\end{array}$ \\
\hline
\end{tabular}

Objective testing:

Saladin Mahmoud Allam (2011) objectivity is the freedom from prejudice, intolerance, and non-introduction of subjective factors in the judgments of the researcher. The test (composite) was simple and easy to understand and implement by the research sample, in addition to the units of measurement are (degree / time), which indicates that the test (composite) objective and significant because the error level of the test (composite) less than the level (0.05 As shown in Table 3.

Table (3) shows the objectivity

\begin{tabular}{|l|l|l|l|l|}
\hline \multicolumn{2}{|l|}{$\begin{array}{l}\text { Rolling speed from the side and pulling the } \\
\text { ball and scoring on a goal divided at } 10 \mathrm{~m}\end{array}$} & $\begin{array}{l}\text { Rolling speed, handling and } \\
\text { scoring after the ball bounced } \\
\text { from a Swedish terrace from a } \\
\text { distance of } 10 \mathrm{~m}\end{array}$ & $\begin{array}{l}\text { The name of the } \\
\text { test }\end{array}$ \\
\hline Error level & The value of $\mathrm{t}$ & Error level & The value of $\mathrm{t}$ & Objectivity \\
\hline 0.000 & 0.908 & 0.000 & 0.921 & \\
\hline
\end{tabular}


Difficulty level for testing:

"If the tests used are suitable for the research sample in terms of degree of ease and difficulty, this will lead to their normal distribution and obtaining the form of the data curve"

To verify the difficulty level of the test (compound) for a sample of the sample, the researcher used the torsion coefficient law. (4)

Table (4)

Shows the level of difficulty and ease of testing

\begin{tabular}{l|l|l|l|l|l}
$\begin{array}{l}\text { Torsion } \\
\text { coefficient }\end{array}$ & Mediator & $\begin{array}{l}\text { standard } \\
\text { deviation }\end{array}$ & $\begin{array}{l}\text { Arithmetic } \\
\text { mean }\end{array}$ & $\begin{array}{l}\text { measruing } \\
\text { unit }\end{array}$ & the exams \\
\hline 0.247 & 0.765 & 0.377 & 0.792 & $\begin{array}{l}\text { Degree/ } \\
\text { second }\end{array}$ & $\begin{array}{l}\text { Rolling speed from the side and } \\
\text { pulling the ball and scoring on a } \\
\text { goal divided at } 10 \mathrm{~m}\end{array}$ \\
\hline
\end{tabular}

rationing experience for testing

The researcher applied the test on Sunday and Wednesday $(20,17)$ / 3/2018 on a sample of (72) players from the research community and were randomly selected.

$\square$ Statistical means

The Statistical Package (SPSS.Ver15) was used.

\section{RESULT AND DISCUSSION:}

After applying the test to the research sample, the results were obtained and processed statistically to facilitate the analysis process, as the researcher obtained the averages and standard deviations of the candidate test

Table (5)

Shows the arithmetic, median, standard deviation, range, minimum value and highest value of the test results for the sample. Table $(5($

Standard and percentage metadata

\begin{tabular}{|l|l|l|l|}
\hline percentage & the number & Standard level & Raw grade \\
\hline $4.16 \%$ & 3 & very good & 1.459 And more \\
\hline $30.55 \%$ & 22 & good & $1.459-1.144$ \\
\hline $34.72 \%$ & 25 & Average & $1.143-0.830$ \\
\hline $27.77 \%$ & 20 & Acceptable & $0.829-0.515$ \\
\hline $2.77 \%$ & 2 & Weak & $0.14-0.20$ \\
\hline $100 \%$ & 72 & $\begin{array}{l}\text { standard deviation }= \\
0.471\end{array}$ & Arithmetic mean $=0,892$ \\
\hline & & \multicolumn{2}{|c|}{ Term $=1.25$} \\
\hline
\end{tabular}

The level (very good) obtained (3) repetitions in the test measurement, and a percentage of (4.16\%), the level (good) has got (22) repetitions, and a percentage of (30.55\%), and the level (average) (25) repetitions, with a percentage of (34.72\%), while the level (acceptable) got (20) repetitions, and a percentage of (27.77\%), and the level (weak) got (2) repetitions, and a percentage of $(2,77 \%)$ of the total sample of (72) players

$\square$ to standard scores relay method to test

The results showed that the fixed number $=0.047$ 
Table (6)

Standard scores relay method to test the rolling speed from the side and pull the ball and scoring on a goal divided at $10 \mathrm{~m}$

\begin{tabular}{|c|c|c|c|c|c|c|c|c|c|}
\hline $\begin{array}{l}\text { Standard } \\
\text { score }\end{array}$ & $\begin{array}{l}\text { Raw } \\
\text { grade }\end{array}$ & $\begin{array}{l}\text { Standard } \\
\text { score }\end{array}$ & $\begin{array}{l}\text { Raw } \\
\text { grade }\end{array}$ & $\begin{array}{l}\text { Standard } \\
\text { score }\end{array}$ & $\begin{array}{l}\text { Raw } \\
\text { grade }\end{array}$ & $\begin{array}{l}\text { Standard } \\
\text { score }\end{array}$ & $\begin{array}{l}\text { Raw } \\
\text { grade }\end{array}$ & $\begin{array}{l}\text { Standard } \\
\text { score }\end{array}$ & $\begin{array}{l}\text { Raw } \\
\text { grade }\end{array}$ \\
\hline 20 & -0.565 & 40 & 0.375 & 60 & 1.315 & 80 & 2.255 & 100 & 3.195 \\
\hline 19 & -0.612 & 39 & 0.328 & 59 & 1.268 & 79 & 2.208 & 99 & 3.148 \\
\hline 18 & -0.659 & 38 & 0.281 & 58 & 1.221 & 78 & 2.161 & 98 & 3.101 \\
\hline 17 & -0.706 & 37 & 0.234 & 57 & 1.174 & 77 & 2.114 & 97 & 3.054 \\
\hline 16 & -0.753 & 36 & 0.187 & 56 & 1.127 & 76 & 2.067 & 96 & 3.007 \\
\hline 15 & -0.8 & 35 & 0.14 & 55 & 1.08 & 75 & 2.02 & 95 & 2.96 \\
\hline 14 & -0.847 & 34 & 0.093 & 54 & 1.033 & 74 & 1.973 & 94 & 2.913 \\
\hline 13 & -0.894 & 33 & 0.046 & 53 & 0.986 & 73 & 1.926 & 93 & 2.866 \\
\hline 12 & -0.941 & 32 & -0.001 & 52 & 0.939 & 72 & 1.879 & 92 & 2.819 \\
\hline 11 & -0.988 & 31 & -0.048 & 51 & 0.892 & 71 & 1.832 & 91 & 2.772 \\
\hline 10 & -1.035 & 30 & -0.095 & 50 & 0.845 & 70 & 1.785 & 90 & 2.725 \\
\hline 9 & -1.082 & 29 & -0.142 & 49 & 0.798 & 69 & 1.738 & 89 & 2.678 \\
\hline 8 & -1.129 & 28 & -0.189 & 48 & 0.751 & 68 & 1.691 & 88 & 2.631 \\
\hline 7 & -1.176 & 27 & -0.236 & 47 & 0.704 & 67 & 1.644 & 87 & 2.584 \\
\hline 6 & -1.223 & 26 & -0.283 & 46 & 0.657 & 66 & 1.597 & 86 & 2.537 \\
\hline 5 & -1.27 & 25 & -0.33 & 45 & 0.61 & 65 & 1.55 & 85 & 2.49 \\
\hline 4 & -1.317 & 24 & -0.377 & 44 & 0.563 & 64 & 1.503 & 84 & 2.443 \\
\hline 3 & -1.364 & 23 & -0.424 & 43 & 0.516 & 63 & 1.456 & 83 & 2.396 \\
\hline 2 & -1.411 & 22 & -0.471 & 42 & 0.469 & 62 & 1.409 & 82 & 2.349 \\
\hline 1 & -1.458 & 21 & -0.518 & 41 & 0.422 & 61 & 1.362 & 81 & 2.302 \\
\hline
\end{tabular}

Discuss the results of the rolling speed test index from the side and pull the ball and scoring on a divided goal at $10 \mathrm{~m}$ In Table (5), we note that there is a difference in the the highest percentage achieved is the average level percentage of the standard levels obtained by the players, $(34.72 \%)$ followed by a good level of $(30.55 \%)$. The use 
(IJRSSH) 2020, Vol. No. 10, Issue No. I, Jan-Mar

of teaching aids facilitates the transfer of information from the coach to the players, and this helps the process of learning and reach the best results and levels in improving the skill of scoring in the game of football for the halls.

Because the skill of scoring is one of the weapons of the good team that threatens the competition teams, and players who have the speed of scoring from different areas of the stadium is considered the source of the main threat that threatens the opponent, so most of the coaches during the educational unit focused on the skill of scoring from the central areas and sides of the stadium, because it is a process Scoring goals that excite competition and the public as stressed (EmadZubair Ahmed 2005) "In the game of football for the lounges are many scoring opportunities because the playing area is small and the ball is characterized by speed and movement and that the time to reach the goal (competitor) is lightning fast" () and sees (Mufti Ibrahim 2010) The term scoring: "is yachting Ululation player insert the ball to the goal of either using force or speed or accuracy."

This refers to the average level of the rolling speed test index from the side, pulling the ball and scoring on a goal divided at $10 \mathrm{~m}$ in the research sample.

The researcher believes that the use of aids and compound exercises have a direct impact on the level of players in the test scoring from the side during competitions, and must work by coaches to reach high levels in the game of football for the lounges, especially the school community of students.

\section{CONCLUSIONS:}

- The test proved valid to measure the speed and accuracy of the scoring from the side of the football players for the intermediate stage in Baghdad province.
e-ISSN: 2249-4642, p-ISSN: 2454-4671

- The test designed by the researcher was extracted (5) standard levels.

\section{ENDORSEMENT:}

- Use the test designed by the researcher in measuring the speed and accuracy of scoring from the side of the football players of the halls of the intermediate stage in the province of Baghdad.

- Allocate some of the combined exercises in the development of speed and accuracy of scoring from the side of the football players of the halls.

- Finding degrees and standard levels for the preparatory stage players in Baghdad and Iraq.

\section{REFERENCES:}

- Expresses Khyoun: kinetic learning between principle and practice, i 2, Baghdad, Good Word Press, 2010, p. 45.

- Hisham Al-Zyoud and Nader Alayyan: Principles of Measurement and Evaluation in Education, 2nd Edition, (Amman, Dar Al Kutub for Printing, Publishing and Distribution, 1998, p. 148)

- Salahuddin Mahmoud Allam (2011). Measurement and educational and psychological evaluation, I, Cairo, Dar Arab Thought, p. 277.

- QaisNaji and Bastawisy Ahmed (1987). Tests and Principles of Statistics in the Sports Field, Baghdad: Higher Education Press, p. 131.

- Wadih Yassin and Hassan Mohammed Al-Obeidi (1999). Statistical Applications and Computer Uses in Physical Education Research, Mosul, Dar Al Kutub for Printing and Publishing, p. 165.

- ImadZubair: Technique and tactics in the pentathlon football, i 1, Baghdad, Sinbad for printing, 2005, p. 76.

- Mufti Ibrahim (2010). Comprehensive reference football, Cairo, Dar al-Kitab al-Hadith p. 160 


\section{ANNEX (1)}

Shows the names of professors and experts

\begin{tabular}{|c|c|c|c|c|}
\hline Workplace & Jurisdiction & The name & $\begin{array}{l}\text { The scientific } \\
\text { title }\end{array}$ & sequence \\
\hline $\begin{array}{l}\text { University of Baghdad / } \\
\text { College of } \begin{array}{r}\text { Physical } \\
\text { Education and Sports } \\
\text { Sciences }\end{array}\end{array}$ & Kinetic learning (football) & muhamadeabdalhusayn & Prof. Dr. & 1 \\
\hline 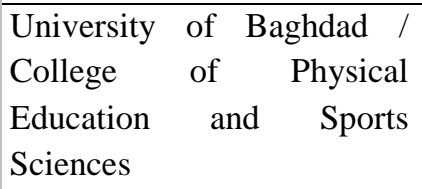 & Sports Science (Football) & Sabah Qasim & Prof. Dr. & 2 \\
\hline $\begin{array}{lcr}\text { University } & \text { of Baghdad / } \\
\text { College } & \text { of } & \text { Physical } \\
\text { Education } & \text { and } & \text { Sports } \\
\text { Sciences } & & \end{array}$ & Physiology & Mohammed Jawad & Prof. Dr. & 3 \\
\hline $\begin{array}{lcr}\text { University } & \text { of Baghdad / } \\
\text { College } & \text { of } & \text { Physical } \\
\text { Education } & \text { and } & \text { Sports } \\
\text { Sciences } & & \end{array}$ & Kinetic Learning & tariqnizar & Prof. Dr. & 4 \\
\hline $\begin{array}{lcr}\text { University of Baghdad / } \\
\text { College of } \\
\text { Education } \\
\text { Sciences }\end{array}$ & Sports Science (Football) & DhiaNaji & Prof. Dr. & 5 \\
\hline $\begin{array}{lcr}\text { University } & \text { of Baghdad / } \\
\text { College } & \text { of } & \text { Physical } \\
\text { Education } & \text { and } & \text { Sports } \\
\text { Sciences } & & \end{array}$ & Test and measure & aseadlazim & Prof. Dr. & 6 \\
\hline $\begin{array}{lcr}\text { University of Baghdad / } \\
\text { College of } \\
\text { Education } \\
\text { Sciences } & & \end{array}$ & (Football) & najikazim & Prof. Assist. Dr. & 7 \\
\hline $\begin{array}{lcr}\text { University } & \text { of } \text { Baghdad / } \\
\text { College } & \text { of } & \text { Physical } \\
\text { Education } & \text { and } & \text { Sports } \\
\text { Sciences } & & \end{array}$ & Sports Science (Football) & wamidshamilkamil & Prof. Assist. Dr. & 8 \\
\hline $\begin{array}{lcr}\text { University of Baghdad / } \\
\text { College of } \\
\text { Education } \\
\text { Sciences } & & \end{array}$ & Sports Science (Football) & muhsineali & Prof & 9 \\
\hline
\end{tabular}

